\title{
Biosensor Nitrit Optik Berasaskan Hemoglobin Terpegun pada Mikrosfera Poliakrilat
}

(Optical Nitrite Biosensor based on Hemoglobin-Immobilized Polyacrylate Microspheres)

\author{
SYAMIMI HASLAN, LING Ling TAN*,LEE YOOK HENG \& GOH CHOO TA
}

\begin{abstract}
ABSTRAK
Biosensor optik berasaskan hemoglobin (Hb) terpegun pada mikrosfera poli(n-butil akrilat-co-N-akriloksisuksinimida) [poli(nBA-NAS)] telah dibangunkan bagi mengesan kepekatan ion nitrit ( $\mathrm{NO}_{2}^{-}$). Kompleks HEM ferum dalam Hb memangkinkan tindak balas penurunan ion $\mathrm{NO}_{2}^{-}$kepada nitrik oksida (NO) lalu bergabung dengan deoksihemoglobin $\left(\mathrm{HbFe}^{2+}\right)$ membentuk kompleks ferum-nitrosil-hemoglobin ( $\left.\mathrm{HbFe}^{2+}-\mathrm{NO}\right)$ yang berwarna hijau kekuningan. Spektrofotometer pantulan gentian optik digunakan untuk memantau kepekatan ion $\mathrm{NO}_{2}^{-}$secara kuantitatif berdasarkan perubahan warna Hb terpegun pada mikrosfera poliakrilat daripada perang kemerahan ke hijau kekuningan pada panjang gelombang pantulan maksimum $668 \mathrm{~nm}$. Pencirian terhadap biosensor nitrit reflektometrik melibatkan ujian kesan pH, kesan kepekatan Hb, julat rangsangan linear, kebolehasilan, jangka hayat dan kesan gangguan ion telah dijalankan. Biosensor ion $\mathrm{NO}_{2}^{-}$optik terbangun memaparkan julat linear dinamik daripada 5 hingga $50 \mathrm{mg} \mathrm{mL}^{-1}\left(R^{2}=0.9894\right)$ pada pH7.0 dengan had pengesanan (LOD) sebanyak $3.3 \mathrm{mg} \mathrm{mL}^{-1}$ dan nilai sisihan piawai relatif (RSD) kebolehasilan biosensor sebanyak 5.8\%. Jangka hayat biosensor optik nitrit tersebut adalah selama 36 hari dan majoriti ion asing yang sering wujud bersama ion $\mathrm{NO}_{2}^{-}$dalam sampel air semula jadi tidak menunjukkan kesan gangguan yang bererti terhadap penentuan ion $\mathrm{NO}_{2}^{-}$menggunakan biosensor optik terbangun kecuali ion $\mathrm{Hg}^{2+}, \mathrm{Ag}^{+}, \mathrm{Br}$ dan $\mathrm{S}^{2-}$
\end{abstract}

Kata kunci: Biosensor; hemoglobin; mikrosfera akrilik; penentuan nitrit

\section{ABSTRACT}

Optical biosensor based on hemoglobin $(\mathrm{Hb})$ immobilized on the poly(n-butyl acrylate-co-N-acryloxysuccinimide) microspheres has been developed for the detection of nitrite $\left(\mathrm{NO}_{2}^{-}\right)$ion concentration. The iron HEM complex in the $\mathrm{Hb}$ catalyzed the reduction of $\mathrm{NO}_{2}^{-}$ion to nitric oxide (NO) followed by binding with deoxyhemoglobin $\left(\mathrm{HbFe}^{2+}\right)$ to form the yellowish green iron-nitrosyl-hemoglobin $\left(\mathrm{HbFe}^{2+}-\mathrm{NO}\right)$ complex. Fiber optic reflectance spectrophotometer was used to monitor the $\mathrm{NO}_{2}^{-}$ion concentration quantitatively based on colour change of the immobilized Hb on the polyacrylate microspheres from reddish brown to yellowish green at the maximum reflectance wavelength of $668 \mathrm{~nm}$. Characterization of the reflectometric nitrite biosensor encompassed $\mathrm{pH}$ effect, $\mathrm{Hb}$ concentration effect, linear response range, reproducibility, shelf life and ion interference effect studies had been conducted. The developed optical $\mathrm{NO}_{2}{ }^{-}$ion biosensor exhibited dynamic linear range from 5 to $50 \mathrm{mg} \mathrm{mL}^{-1}\left(R^{2}=0.9894\right)$ at pH7.0 with a limit of detection (LOD) of $3.3 \mathrm{mg} \mathrm{mL}^{-1}$ and reproducibility relative standard deviation (RSD) value of the biosensor at 5.8\%. The shelf life of the optical nitrite biosensor is about 36 day and majority foreign ions that are often co-exist with $\mathrm{NO}_{2}^{-}$ion in the natural water sample did not show significant interference effect towards the determination of $\mathrm{NO}_{2}^{-}$ion using the developed optical biosensor except $\mathrm{Hg}^{2+}, \mathrm{Ag}^{+}, \mathrm{Br}$ and $\mathrm{S}^{2-}$ ions.

Keywords: Acrylic microsphere; biosensor; hemoglobin; nitrite determination

\section{PENGENALAN}

Pertumbuhan penduduk dan teknologi yang pesat telah menyumbang kepada peningkatan kawasan perindustrian. Hal ini secara tidak langsung menghasilkan corak pertumbuhan yang tidak lestari dan menyebabkan kemusnahan sumber asas semula jadi. Pembangunan yang tidak terkawal turut mengakibatkan pencemaran air persekitaran yang serius. Peningkatan permintaan air bersih menyebabkan persaingan dalam kalangan pelbagai sektor pengguna air. Pertumbuhan ekonomi yang berterusan mengeruhkan lagi keadaan (Raja Dato' Zaharaton 2004). Pencemaran alam sekitar yang menjejaskan kesihatan manusia serta pembangunan sosioekonomi menjadi keprihatinan global. Kehadiran bahan pencemar alam sekitar terutamanya bahan toksin kimia, menimbulkan kebimbangan kesihatan awam yang serius (Koedrith et al. 2015).

Nitrit hadir sebagai bahan pencemar dalam air minuman daripada air bawah tanah dan telaga. Terdapat banyak sumber nitrogen semula jadi mahupun antropogenik yang boleh menyebabkan air bawah tanah dicemari oleh nitrit. Peningkatan pencemaran air minuman kebiasaannya disebabkan oleh penggunaan baja dan pembuangan sampah komersial yang meluas (Ward et al. 2005). Bahan buangan 
seperti tanah pertanian yang dibaja, air sisa industri, fidlot haiwan, tangki septik dan saliran bandar merupakan antara sumber antropogenik utama pencemaran nitrit air bawah tanah (Samaneh Khademikia et al. 2013). Nitrit juga digunakan dalam pemprosesan makanan, iaitu bertujuan untuk menaikkan warna dan menyebarkan aktiviti antimikrob bagi memelihara produk berasaskan daging (Butler 2014).

Ion nitrit $\left(\mathrm{NO}_{2}^{-}\right)$mengandungi nitrogen yang berada dalam keadaan pengoksidaan yang tidak stabil. Ia boleh bertindak balas dengan sebatian organik semula jadi atau sintetik yang dikenali sebagai amina sekunder atau amida dalam makanan atau air, lalu membentuk sebatian baru sama ada nitrosoamina atau nitrosoamida, yang merupakan sebatian karsinogen (Bryan et al. 2012). Methemoglobinemia, juga dikenali sebagai blue baby syndrome dilihat pada bayi yang diberi susu rumusan yang dibancuh dengan air tercemar nitrit. Methemoglobinemia merujuk kepada keadaan anemia yang disebabkan oleh pengoksidaan ion ferus oleh nitrit dalam hemoglobin $\left(\mathrm{HbFe}^{2+}\right)$ kepada ion ferik secara tidak berbalik dan menyebabkan hemoglobin bertukar menjadi methemoglobin $\left(\mathrm{HbFe}^{3+}\right)$. Hal ini boleh menyebabkan sianosis, hipoksemia tisu dan dalam kes yang lebih teruk boleh menyebabkan kematian (Quek et al. 2015). Bayi lebih cenderung kepada penyakit methemoglobinemia disebabkan oleh had ketinggian fizikal serta perkembangan saraf mereka yang masih di peringkat awal menghalang pengangkutan oksigen (Moorcroft et al. 2001).

Potensi ketoksikan nitrit menimbulkan kerisauan, maka rangka kerja teratur telah dihasilkan bertujuan untuk mengawal kadar nitrit dalam persekitaran, termasuklah dalam produk makanan. Beberapa kaedah analisis seperti spektrometri, pendarfluor, ujian Griess, kromatografi ion, kimipendarcahaya dan elektrokimia telah digunakan dalam penentuan nitrit terutamanya dalam sampel air. Walau bagaimanapun, teknik tersebut masing-masing mempunyai kelemahan tersendiri, kebanyakannya memakan masa, memerlukan tenaga kerja mahir dan peralatan yang mahal. Kaedah yang paling banyak digunakan dalam penentuan nitrit ialah kaedah spektroskopi kerana had pengesanannya yang rendah dan protokol jenis asai yang mudah digunakan.

Biosensor memenuhi kriteria sebagai kaedah yang berkos rendah, peka, selektif, stabil dan memakan masa analisis yang pendek (Wen et al. 2014). Kelebihan utama biosensor berbanding dengan kaedah kovensional yang lain ialah keupayaannya untuk digunakan secara in-situ, mudah alih, menunjukkan potensi yang tinggi untuk pengecilan serta kebolehannya untuk mengesan bahan pencemar dalam matriks kompleks dengan perawatan sampel yang minima. Kini, biosensor telah digunakan oleh pelbagai industri dalam penyediaan maklumat yang mencukupi dalam asai rutin dan pemeriksaan sampel (Tereshchenko et al. 2016).

Dalam kajian ini, biosensor ion nitrit optik berasaskan hemoglobin $(\mathrm{Hb})$ telah dibangunkan. Mikrosfera poli(nbutil akrilat-co- $N$-akriloksisuksinimida) [poli( $n$ BA-NAS)] telah digunakan sebagai matriks pemegun $\mathrm{Hb}$. Molekul
$\mathrm{Hb}$ dipegunkan ke atas mikrosfera kopolimer poli( $n \mathrm{BA}$ NAS) melalui ikatan kovalen amida antara kumpulan berfungsi suksinimida pada mikrosfera akrilik dan kumpulan berfungsi amina pada Hb. Kumpulan HEM dalam rantai polipeptida $\mathrm{Hb}$ bertanggungjawab memangkinkan tindak balas penurunan nitrit $\left(\mathrm{NO}_{2}^{-}\right)$kepada nitrik oksida (NO), sementara $\mathrm{Hb}$ tersebut $\left(\mathrm{HbFe}^{2+}\right)$ teroksida kepada methemoglobin $\left(\mathrm{HbFe}^{3+}\right)$. Oleh kerana NO yang terhasil mempunyai keafinan yang tinggi terhadap kompleks HEM ferum dalam $\mathrm{Hb}$, ia kemudian bergabung dengan deoksihemoglobin $\left(\mathrm{HbFe}^{2+}\right)$ membentuk kompleks ferum-nitrosil-hemoglobin $\left(\mathrm{HbFe}^{2+}-\mathrm{NO}\right)$ berwarna hijau kekuningan yang boleh dipantau secara reflektometrik menggunakan spektrofotometer pantulan gentian optik. Persamaan (1) menunjukkan persamaan kimia bagi tindak balas penurunan ion nitrit oleh $\mathrm{Hb}$ terpegun pada mikrosfera kopolimer poli( $n$ BA-NAS) dan Persamaan (2) mewakili tindak balas pembentukan kompleks hijau kekuningan ferum-nitrosil-hemoglobin antara deoksihemoglobin $\left(\mathrm{HbFe}^{2+}\right)$ dan NO.

$$
\begin{gathered}
\begin{array}{c}
\mathrm{HbFe}(\mathrm{II})+\mathrm{NO}_{2}^{-}+\mathrm{H}^{+} \rightarrow \mathrm{HbFe}(\mathrm{III})+\mathrm{NO}+\mathrm{OH}^{-} \\
\text {deoksihemoglobin nitrit } \\
\text { methemoglobin nitrik oksida }
\end{array} \\
\begin{array}{c}
\mathrm{HbFe}(\mathrm{II}) \\
\text { deoksihemoglobin nitrik oksida ferum-nitrosil-hemoglobin }
\end{array}
\end{gathered}
$$

\section{BAHAN DAN KAEDAH}

\section{BAHAN KIMIA}

Bahan kimia yang digunakan dalam kajian ini adalah seperti serbuk beku-kering hemoglobin $(\mathrm{Hb})$, natrium nitrit $\left(\mathrm{NaNO}_{2}\right), \mathrm{N}$-akriloksisuksinimida (NAS) dan 1,6-heksanadiol diakrilat (HDDA) yang diperoleh daripada Sigma-Aldrich. Monomer $n$-butil akrilat ( $n \mathrm{BA}$ ) daripada $\mathrm{BDH}$, natrium dodesil sulfat (SDS) daripada Systerm dan 2,2-dimetoksi-2-fenilasetofenon (DMPP) dari Fluka. Kesemua bahan kimia yang digunakan dalam kajian ini adalah bergred analitik dan air ternyahion digunakan bagi setiap penyediaan larutan akueus dan pembersihan alat kaca. Larutan $\mathrm{Hb}$ disediakan dengan melarutkan serbuk beku-kering $\mathrm{Hb}$ dalam larutan penimbal kalium fosfat $0.1 \mathrm{M}$ pada $\mathrm{pH}$ 7.0. Larutan nitrit juga disediakan dengan menggunakan larutan penimbal yang sama dengan melarutkan natrium nitrit dalam kuantiti yang diperlukan. Larutan penimbal tersebut disediakan berdasarkan kaedah yang dirujuk daripada Handbook of Chemistry and Physics (Robert 1972).

\section{INSTRUMENTASI}

Alat sonikasi (Elmasonic), pengempar (HERMLE Z230A, $5500 \mathrm{rpm}$ ) dan unit sinar ultra lembayung (UV, R.S. Ltd) digunakan semasa penghasilan mikrosfera poli( $n$ BA-NAS). Unit pendedahan UV tersebut memancarkan cahaya UV (15 W) pada panjang gelombang $350 \mathrm{~nm}$. Saiz dan morfologi mikrosfera akrilik diperhatikan menggunakan mikroskop 
elektron imbasan (SEM, LEO 1450VP) pada voltan pecutan $3 \mathrm{kV}$ dan pembesaran sebanyak $2 \mathrm{kX}$. Spektrofotometer ultra lembayung-nampak (Varian-Cary Win UV 50) digunakan dalam analisis kestabilan foto larutan $\mathrm{Hb}$ dan spektrofotometer pantulan gentian optik digunakan bagi mengukur rangsangan biosensor ion $\mathrm{NO}_{2}{ }^{-}$. Pengukuran $\mathrm{pH}$ dijalankan menggunakan meter pH (MeterLab PHM 210) yang dilengkapi dengan elektrod kaca.

\section{PENYEDIAAN MIKROSFERA KOPOLIMER POLI(NBA-NAS)}

Mikrosfera kopolimer poli( $n$ BA-NAS) disediakan melalui kaedah fotopempolimeran dalam bentuk emulsi. Secara ringkasnya, mikrosfera akrilik tersebut disediakan dengan mencampurkan $7 \mathrm{~mL}$ monomer $n \mathrm{BA}, 0.01 \mathrm{~g}$ surfaktan SDS, $450 \mu \mathrm{L}$ agen taut silang HDDA, $10 \mathrm{mg}$ monomer NAS, $0.10 \mathrm{~g}$ bahan pemula fotopempolimeran DMPP dan $15 \mathrm{~mL}$ air ternyahion ke dalam sebuah botol sintilasi. Campuran tersebut kemudiannya disonikasi pada suhu bilik $\left(25^{\circ} \mathrm{C}\right)$ selama $10 \mathrm{~min}$. Kemudian, emulsi berwarna putih susu yang terhasil dipindahkan ke piring petri dan didedahkan kepada cahaya UV bawah unit sinar UV selama $600 \mathrm{~s}$ dalam persekitaran gas nitrogen bagi membolehkan proses fotopempolimeran berlaku. Seterusnya, mikrosfera kopolimer yang terhasil dipindahkan ke dalam tiub pengempar $15 \mathrm{~mL}$ dan ditambahkan dengan larutan penimbal kalium fosfat 0.1 M (pH7.0). Mikrosfera diasingkan dengan alat pengempar pada kelajuan 6000 rpm selama $10 \mathrm{~min}$. Sebanyak tiga kitaran basuh dilakukan dengan bilasan menggunakan larutan penimbal kalium fosfat $0.1 \mathrm{M}$ (pH7.0) agar mikrosfera akrilik dapat diasingkan daripada bahan kimia berlebihan yang tidak bertindak balas dalam sintesis mikrosfera poli( $n$ BA-NAS). Mikrosfera akrilik yang tersintesis kemudian dikeringkan pada suhu bilik selama dua hari.

\section{FABRIKASI BIOSENSOR OPTIK NITRIT BERASASKAN HEMOGLOBIN TERPEGUN}

Sebanyak 10 mg mikrosfera poli( $n$ BA-NAS) ditimbang ke dalam penutup tiub mikro pengempar $500 \mu \mathrm{L}$. Ia kemudian dimampatkan secara manual bagi mendapatkan permukaan yang rata. Kemudian, larutan $\mathrm{Hb} 50 \mathrm{mg} \mathrm{mL}^{-1}$ dipipetkan pada permukaan mikrosfera akrilik dan dibiarkan kering semalaman pada suhu $25^{\circ} \mathrm{C}$ bagi membolehkan ikatan kovalen terbentuk antara molekul $\mathrm{Hb}$ dan mikrosfera akrilik. Selepas itu, biosensor berasaskan hemoglobin tersebut dibilas menggunakan larutan penimbal kalium fosfat $0.1 \mathrm{M}$ pada $\mathrm{pH} 7.0$ bagi mengasingkan $\mathrm{Hb}$ yang terjerap secara fizikal pada permukaan mikrosfera akrilik dan dibiarkan dalam keadaan kering suhu ambien normal.

\section{PENCIRIAN TINDAK BALAS ANTARA HEMOGLOBIN TERPEGUN DAN ION NO-}

Pencirian tindak balas antara $\mathrm{Hb}$ terpegun dan ion $\mathrm{NO}_{2}{ }^{-}$melibatkan ujian kesan $\mathrm{pH}$, kesan kepekatan $\mathrm{Hb}$, julat kepekatan dinamik, kebolehasilan, jangka hayat dan kesan gangguan ion telah dijalankan menggunakan spektrofotometer pantulan gentian optik. Uji kaji kesan $\mathrm{pH}$ ke atas rangsangan optik biosensor nitrit dilakukan dengan mengubah $\mathrm{pH}$ larutan penimbal kalium fosfat $0.1 \mathrm{M}$ yang disediakan daripada campuran kalium dihidrogen fosfat $0.1 \mathrm{M}$ dan dikalium hidrogen fosfat 0.1 M sebagai pelarut kepada $60 \mathrm{mg} \mathrm{mL}^{-1}$ ion $\mathrm{NO}_{2}^{-}$. Kajian kesan kepekatan $\mathrm{Hb}$ dijalankan dengan mempelbagaikan kepekatan larutan $\mathrm{Hb}$ yang digunakan dalam pemegunan pada mikrosfera kopolimer poli( $n \mathrm{BA}-\mathrm{NAS})$ daripada 1-220 mg mL $\mathrm{m}^{-1}$ dalam larutan penimbal kalium fosfat 0.1 M. Julat linear dinamik biosensor reflektometrik nitrit ditentukan dengan menggunakan larutan ion $\mathrm{NO}_{2}{ }^{-}$berjulat daripada 5 hingga $80 \mathrm{mg} \mathrm{mL}^{-1}$ pada panjang gelombang patulan $668 \mathrm{~nm}$. Peratusan sisihan piawai relatif (\% RSD) kebolehasilan biosensor ditentukan dengan menggunakan tiga unit biosensor berasaskan poli( $n \mathrm{BA}-\mathrm{NAS})$ terpegun $\mathrm{Hb}$ dalam pengesanan kepekatan ion $\mathrm{NO}_{2}^{-}$pada 20 dan $40 \mathrm{mg} \mathrm{mL} \mathrm{m}^{-1}$. Sebelum pemegunan $\mathrm{Hb}$ dilakukan, ujian kestabilan foto $\mathrm{Hb}$ dalam larutan penimbal kalium fosfat 0.1 M dijalankan dengan mendedahkan larutan $\mathrm{Hb}$ dalam keadaan bercahaya di makmal secara berterusan selama 10 jam dan pengukuran serapan larutan $\mathrm{Hb}$ diambil selang 1 jam dengan spektrofotometer ultra lembayung-nampak pada panjang gelombang serapan maksimum $408 \mathrm{~nm}$. Jangka hayat $\mathrm{Hb}$ terpegun pada mikrosfera poliakrilat juga dikaji dengan sebanyak 45 unit biosensor telah disediakan pada hari pertama dan ukuran keamatan pantulan bagi 3 unit biosensor terhadap pengesanan $60 \mathrm{mg} \mathrm{mL}^{-1}$ ion $\mathrm{NO}_{2}$ - pada $668 \mathrm{~nm}$ dilakukan selang 3 hari dalam tempoh 45 hari. Kajian kesan gangguan ion terhadap biosensor nitrit dikenal pasti dengan memperkenalkan $\mathrm{Hb}$ terpegun kepada beberapa ion gangguan yang biasanya wujud bersama ion $\mathrm{NO}_{2}{ }^{-}$dalam air semula jadi seperti ion $\mathrm{Ca}^{2+}$, $\mathrm{Mg}^{2+}, \mathrm{Al}^{3+}, \mathrm{Cu}^{2+}, \mathrm{Fe}^{3+}, \mathrm{Mn}^{2+}, \mathrm{Cl}^{-}, \mathrm{Cr}^{3+}, \mathrm{C}_{4} \mathrm{H}_{4} \mathrm{O}_{6}{ }^{2-}, \mathrm{Pb}^{2+}, \mathrm{Fe}^{2+}$, $\mathrm{V}^{4+}, \mathrm{I}^{-}, \mathrm{Ag}^{+}, \mathrm{Hg}^{2+}, \mathrm{Br}^{-}$dan $\mathrm{S}^{2-}$. Kepekatan ion gangguan yang dtambahkan ke dalam medium tindak balas antara $\mathrm{Hb}$ terpegun dan ion $\mathrm{NO}_{2}{ }^{-}$ditingkatkan daripada $0.01 \mathrm{mg}$ $\mathrm{mL}^{-1}$ sehingga memberi ralat pantulan relatif sebanyak $\pm 5 \%$ dalam penentuan $25 \mathrm{mg} \mathrm{mL}^{-1}$ ion $\mathrm{NO}_{2}^{-}$pada $\mathrm{pH} 7.0$ dan panjang gelombang $668 \mathrm{~nm}$.

\section{KEPUTUSAN DAN PERBINCANGAN}

Imej SEM dalam Rajah 1 menunjukkan mikrosfera kopolimer poli( $n$ BA-NAS) yang terhasil melalui tindak balas fotopempolimeran emulsi mempunyai purata diameter mikrosfera sebanyak $2.6 \mu \mathrm{m}$. Pengubahsuaian mikrosfera akrilik dengan kumpulan berfungsi suksinimida membolehkan molekul $\mathrm{Hb}$ diikat secara tidak berbalik pada matriks sokongan melalui ikatan kovalen. Bentuk sfera tiga dimensi poli( $n$ BA-NAS) mewujudkan luas kawasan permukaan yang besar kepada pemegunan molekul Hb pada kapasiti muatan yang tinggi. Dengan ini, ia meningkatkan tahap kepekaan biosensor terhadap pengesanan analit sasaran. Selain itu, morfologi poli $(n \mathrm{BA}-$ NAS) berbentuk sfera juga akan memudahkan proses peresapan analit berlaku pada medium tiga dimensi. 


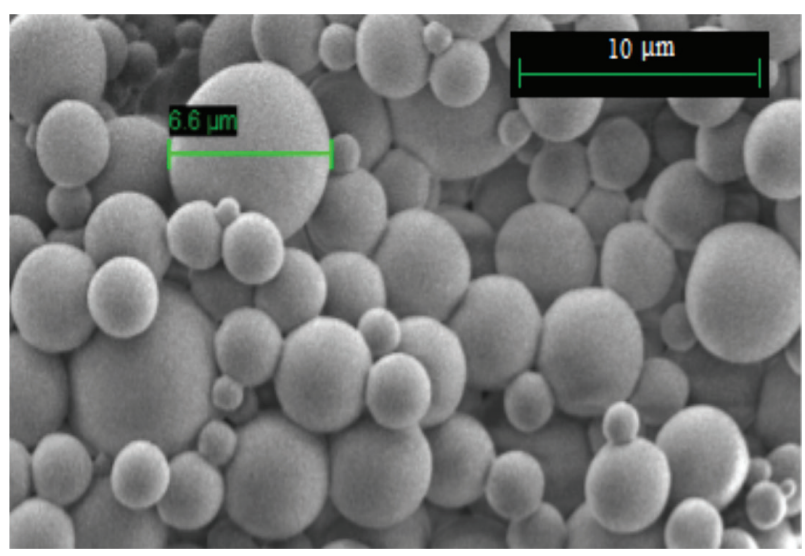

RAJAH 1. Mikrograf SEM poli( $n$ BA-NAS) yang diperolehi daripada mikroskop elektron imbasan pada voltan pecutan $3 \mathrm{kV}$ dan pembesaran sebanyak $2 \mathrm{kx}$

Secara amnya, struktur keseluruhan molekul $\mathrm{Hb}$ merangkumi 4 rantaian polipeptida (globin) yang berkait antara satu sama lain. Setiap unit globin $\mathrm{Hb}$ mengandungi atom ferum $(\mathrm{Fe})$ di pusat dalam keadaan pengoksidaan +2 , iaitu $\mathrm{Fe}^{2+}$ yang berfungsi menurunkan ion $\mathrm{NO}_{2}^{-}$secara tidak berbalik dan membentuk nitrik oksida (NO). Protein HEM tersebut kemudiannya bergabung dengan NO lalu membentuk kompleks ferum-nitrosil-hemoglobin $\left(\mathrm{HbFe}^{2+}\right.$ NO) berwarna hijau kekuningan. Rajah 2 menunjukkan spektrum pantulan biosensor nitrit berasaskan $\mathrm{Hb}$ terpegun pada mikrosfera poliakrilat sebelum (a) dan selepas (b) bertindak balas dengan $60 \mathrm{mg} \mathrm{mL}^{-1}$ ion $\mathrm{NO}_{2}^{-}$pada $\mathrm{pH} 7.0$. Biosensor berasaskan $\mathrm{Hb}$ terpegun pada mikrosfera kopolimer poli( $n$ BA-NAS) adalah berwarna perang kemerahan sebelum bertindak balas dengan ion $\mathrm{NO}_{2}{ }_{2}^{-}$dan menunjukkan keamatan pantulan maksimum pada panjang gelombang $\left(\lambda_{\max }\right) 785 \mathrm{~nm}$. Apabila $60 \mathrm{mg} \mathrm{mL}^{-1}$ ion $\mathrm{NO}_{2}^{-}$ ditindak balaskan dengan $\mathrm{Hb}$ terpegun, perubahan warna biosensor daripada perang kemerahan ke hijau kekuningan yang lebih terang warnanya telah meningkatkan keamatan pantulan pada $\lambda_{\text {max }}$ pada $668 \mathrm{~nm}$ akibat pembentukan kompleks $\mathrm{HbFe}^{2+}-\mathrm{NO}$ terpegun. Spektrum pantulan bagi $\mathrm{Hb}$ terpegun (a) dan kompleks terpegunnya selepas bertindak balas dengan $60 \mathrm{mg} \mathrm{mL}^{-1}$ ion $\mathrm{NO}_{2}^{-}$(b) menunjukkan perbezaaan pantulan relatif maksimum pada $668 \mathrm{~nm}$. Oleh itu, analisis pengoptimuman biosensor ion $\mathrm{NO}_{2}^{-}$yang selanjutnya dilakukan berdasarkan panjang gelombang 668 nm.

Bagi tujuan pengoptimuman tindak balas kimia antara $\mathrm{Hb}$ terpegun dan ion $\mathrm{NO}_{2}^{-}$, eksperimen yang melibatkan larutan ion $\mathrm{NO}_{2}^{-}$pada $\mathrm{pH}$ berbeza telah dijalankan. Berdasarkan Rajah 3, pH optimum bagi penghasilan kompleks hijau kekuningan $\mathrm{HbFe}^{2+}-\mathrm{NO}$ terpegun didapati pada $\mathrm{pH} 7$. Pada $\mathrm{pH}$ yang rendah, ia merangsang tindak balas penurunan ion $\mathrm{NO}_{2}^{-}$oleh protein HEM untuk menghasilkan NO, dan kadar penghasilkan NO adalah paling maksimum pada $\mathrm{pH}$ neutral. Kadar penurunan nitrit spesifik didapati dihalang oleh peningkatan $\mathrm{pH}$ dari $\mathrm{pH} 8$ hingga pH10 (Cerqueira et al. 2013). Analisis kualitatif yang menggunakan larutan $\mathrm{Hb}$ bagi mengesan kehadiran ion $\mathrm{NO}_{2}^{-}$telah pun dilaporkan oleh Aschebrook-Kilfoy et al. (2011) dalam larutan neutral atau sedikit berasid. Dengan itu, medium tindak balas biokimia antara $\mathrm{Hb}$ terpegun dan ion $\mathrm{NO}_{2}{ }_{2}^{-}$ditetapkan pada $\mathrm{pH} 7$ menggunakan larutan penimbal kalium fosfat $0.1 \mathrm{M}$ dalam analisis yang seterusnya.

Rajah 4 menunjukkan plot pantulan pembentukan kompleks $\mathrm{HbFe}^{2+}-\mathrm{NO}$ terpegun melawan kepekatan $\mathrm{Hb}$ yang digunakan dalam pemegunan $\mathrm{Hb}$ pada mikrosfera poliakrilat dalam julat $1-220 \mathrm{mg} \mathrm{mL}^{-1}$. Peningkatan kepekatan $\mathrm{Hb}$ didapati meningkatkan isyarat kepantulan biosensor pada panjang gelombang $668 \mathrm{~nm}$ daripada kepekatan $\mathrm{Hb} 1$ hingga $120 \mathrm{mg} \mathrm{mL}^{-1}$ akibat peningkatan kadar tindak balas penurunan ion $\mathrm{NO}_{2}^{-}$oleh kompleks HEM ferum. Rangsangan biosensor menjadi hampir malar

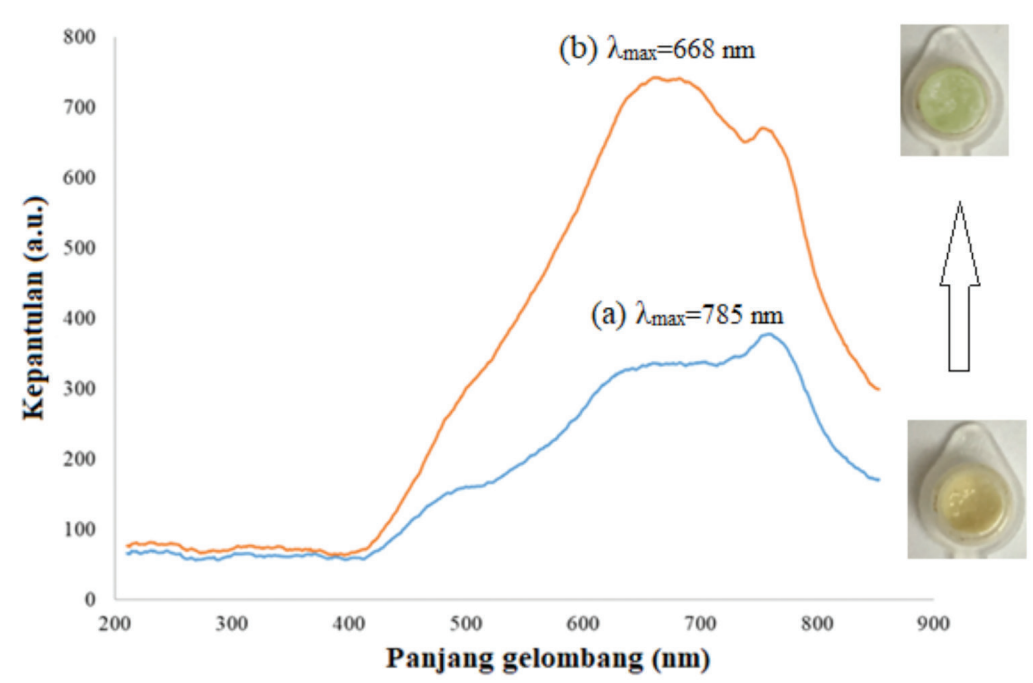

RAJAH 2. Spektra pantulan bagi Hb terpegun pada mikrosfera kopolimer poli( $n$ BA-NAS) (a) dan kompleks terpegunnya selepas bertindak balas dengan $60 \mathrm{mg} \mathrm{mL}^{-1} \mathrm{NO}_{2}^{-}$(b) pada $\mathrm{pH} 7.0$ 


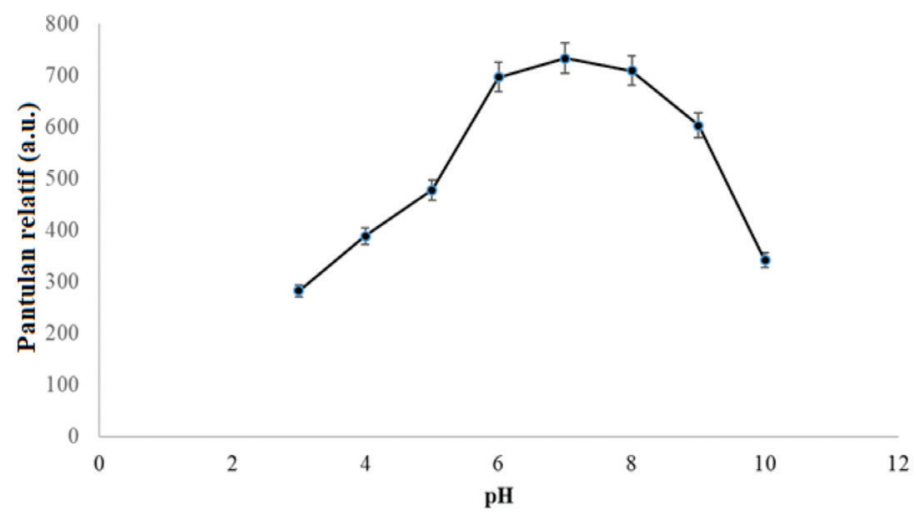

RAJAH 3. Kesan $\mathrm{pH}$ terhadap rangsangan biosensor dalam penentuan $60 \mathrm{mg} \mathrm{mL}^{-1}$ ion $\mathrm{NO}_{2}$ menggunakan larutan penimbal kalium fosfat $0.1 \mathrm{M}$ antara $\mathrm{pH} 3$ hingga $\mathrm{pH} 10(n=3)$

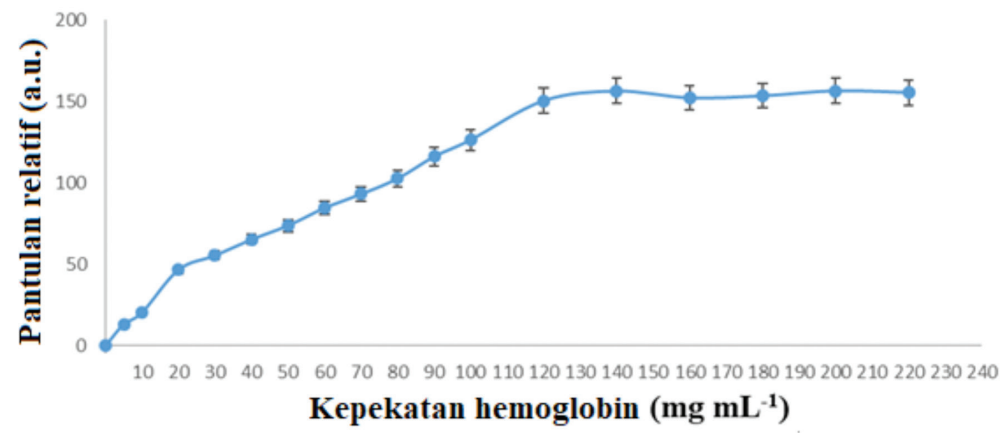

RAJAH 4. Kesan kepekatan $\mathrm{Hb}$ dari 1-220 $\mathrm{mg} \mathrm{mL}^{-1}$ dalam penyediaan biosensor nitrit terhadap pengesanan $60 \mathrm{mg} \mathrm{mL}^{-1}$ ion $\mathrm{NO}_{2}^{-}$pada $\mathrm{pH} 7.0$ dan panjang gelombang $668 \mathrm{~nm}(n=3)$

apabila kepekatan $\mathrm{Hb}$ ditingkatkan daripada 120-220 mg $\mathrm{mL}^{-1}$ dengan kesemua ion $\mathrm{NO}_{2}{ }^{-}$yang hadir telah digunakan dalam tindak balas pembentukan kompleks dengan $\mathrm{Hb}$ dan kepekatan optimum $\mathrm{Hb}$ diperoleh pada $120 \mathrm{mg} \mathrm{mL}^{-1}$.

Rangsangan biosensor reflektometrik pada panjang gelombang $668 \mathrm{~nm}$ terhadap kepekatan ion $\mathrm{NO}_{2}^{-}$berbeza (daripada 5-80 $\mathrm{mg} \mathrm{mL}^{-1}$ ) telah dilakukan untuk memperoleh lengkung kalibrasi biosensor nitrit tersebut (Rajah 5). Kenaikan rangsangan optik biosensor didapati selari dengan peningkatan kepekatan ion $\mathrm{NO}_{2}^{-}$daripada 5 hingga 50

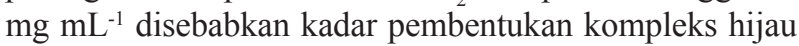
kekuningan $\mathrm{HbFe}^{2+}$-NO terpegun semakin meningkat berkadaran dengan peningkatan kepekatan ion $\mathrm{NO}_{2}{ }_{2}$. Rangsangan pantulan relatif biosensor menjadi malar selepas bertindak balas dengan ion $\mathrm{NO}_{2}^{-}$pada kepekatan melebihi $50 \mathrm{mg} \mathrm{mL}^{-1}$. Ini menunjukkan kehadiran tapak pemangkinan protein HEM yang sedia ada pada permukaan biosensor telah dipenuhi dengan ion $\mathrm{NO}_{2}{ }^{-}$dan kehadiran ion $\mathrm{NO}_{2}{ }^{-}$yang berlebihan tidak dapat digunakan dalam tindak balas pembentukan kompleks dengan $\mathrm{Hb}$ terpegun untuk meningkatkan lagi rangsangan biosensor. Biosensor nitrit menunjukkan julat linear dinamik antara 5 hingga $50 \mathrm{mg}$ $\mathrm{mL}^{-1}\left(\mathrm{R}^{2}=0.9894\right)$ dengan had pengesanan (LOD) yang dikira berdasarkan isyarat blank ditambahkan dengan tiga sisihan piawai blank adalah sebanyak $3.3 \mathrm{mg} \mathrm{mL}^{-1}$. Kebolehasilan biosensor optik ion $\mathrm{NO}_{2}$-juga adalah memuaskan dengan nilai sisihan piawai relatif (RSD) sebanyak 5.8\%.
Untuk menilai keselektifan kaedah yang dicadangkan, kesan ion asing terhadap penentuan nitrit telah dikaji dengan menambah ion asing dalam beberapa kepekatan tertentu ke dalam $25 \mathrm{mg} \mathrm{mL}^{-1}$ larutan ion $\mathrm{NO}_{2}^{-}$. Penentuan nitrit dijalankan dengan menggunakan biosensor reflektometrik terbangun di bawah keadaan optimum. Keputusan dalam Jadual 1 jelas menunjukkan bahawa kebanyakan ion yang sering wujud bersama nitrit dalam sampel air semula jadi hanya menunjukkan kesan gangguan terhadap penentuan ion $\mathrm{NO}_{2}^{-}$pada kepekatan yang tinggi. Walau bagaimanapun, ion $\mathrm{Hg}^{2+}, \mathrm{Ag}^{+}, \mathrm{Br}$ dan $\mathrm{S}^{2-}$ mempunyai had toleransi yang lebih rendah. Masalah kesan gangguan ion ini boleh diatasi dengan menggunakan agen penopeng seperti asid askorbik dan asid etilenadiaminatetraasetik (EDTA) yang sering digunakan sebagai agen pengkelat yang boleh membentuk kompleks dengan pelbagai ion logam. Majoriti ion asing yang dinyatakan dalam Jadual 1 biasanya dijumpai dalam air semula jadi pada kepekatan yang rendah. Oleh itu, kaedah biosensor optik yang dicadangkan masih boleh digunakan untuk menentukan kepekatan nitrit dalam sampel air persekitaran (Butler 2014).

Satu kajian berkaitan kestabilan foto reagen telah dijalankan bagi memantau kemungkinan molekul $\mathrm{Hb}$ dalam larutan penimbal kalium fosfat $0.1 \mathrm{M}$ mengalami penguraian apabila didedahkan secara berterusan kepada punca cahaya dalam jangka masa yang lama. Untuk tempoh pemantauan berterusan selama 10 jam, nilai RSD 


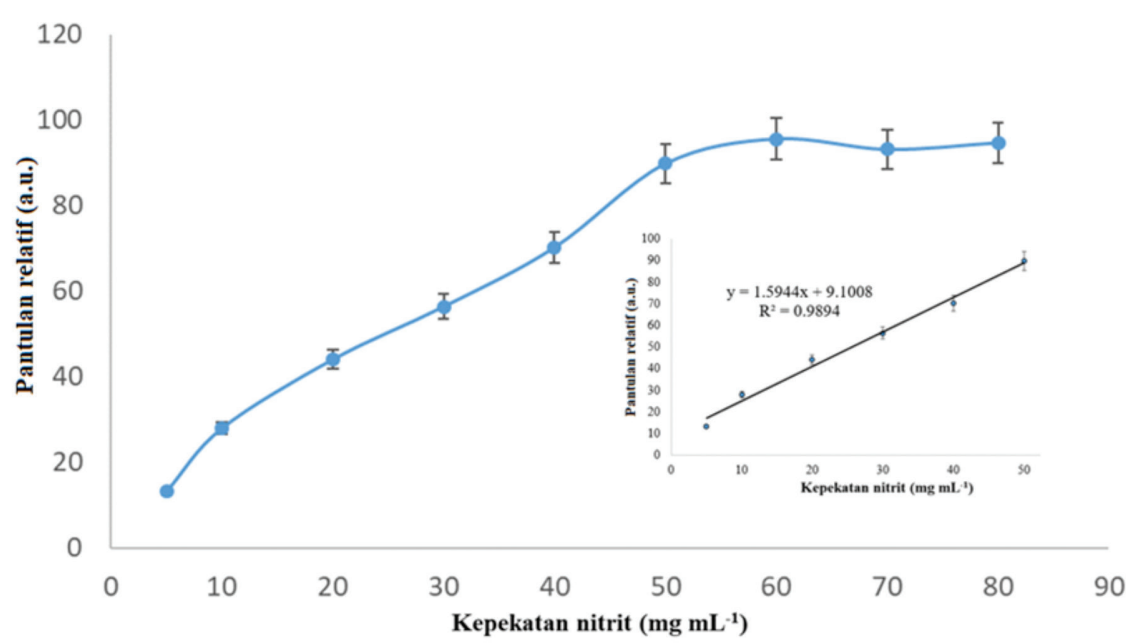

RAJAH 5. Lengkung rangsangan biosensor terhadap kepekatan ion $\mathrm{NO}_{2}^{-}$- dari 5 hingga $80 \mathrm{mg} \mathrm{mL}^{-1}$ pada pH7.0 dan panjang gelombang $668 \mathrm{~nm}(n=3)$. Rajah sisipan menunjukkan rangsangan linear biosensor dalam julat 5-50 $\mathrm{mg} \mathrm{mL}^{-1}$ ion $\mathrm{NO}_{2}^{-}(n=3)$

JADUAL 1. Kesan ion asing terhadap penentuan $25 \mathrm{mg}$ $\mathrm{mL}^{-1}$ ion $\mathrm{NO}_{2}^{-}$pada $\mathrm{pH} 7.0$ dan panjang gelombang $668 \mathrm{~nm}$ menggunakan kaedah biosensor reflektometrik $(n=3)$

\begin{tabular}{cc}
\hline Ion gangguan & Had toleransi $\left(\mathrm{mg} \mathrm{mL}^{-1}\right)$ \\
\hline $\mathrm{Ca}^{2+}, \mathrm{Mg}^{2+}$ & 150 \\
$\mathrm{Al}^{3+}, \mathrm{Cu}^{2+}$ & 150 \\
$\mathrm{Fe}^{3+}, \mathrm{Mn}^{2+}$ & 50 \\
$\mathrm{Cl}^{-}$ & 300 \\
$\mathrm{Cr}^{3+}$ & 30 \\
$\mathrm{C}_{4} \mathrm{H}_{4} \mathrm{O}_{6}^{2-}$ & 20 \\
$\mathrm{~Pb}^{2+}, \mathrm{Fe}^{2+}, \mathrm{V}^{4+}, \mathrm{I}^{-}$ & 2.5 \\
$\mathrm{Ag}^{+}$ & 0.3 \\
$\mathrm{Hg}^{2+}, \mathrm{Br}^{2-}$ & 0.15 \\
$\mathrm{~S}^{2-}$ & 0.01 \\
\hline
\end{tabular}

serendah $2.1 \%$ diperoleh menunjukkan $\mathrm{Hb}$ dalam larutan bebas adalah cukup stabil walaupun terdedah kepada sumber cahaya selama 10 jam pada suhu $25^{\circ} \mathrm{C}$. Kajian jangka hayat dijalankan dengan memerhatikan keupayaan $\mathrm{Hb}$ terpegun untuk memberi bacaan keamatan pantulan yang maksimum selama 45 hari dengan isyarat biosensor diambil selang tiga hari. Untuk jangka hayat biosensor nitrit yang dibangunkan berdasarkan $\mathrm{Hb}$ terpegun pada mikrosfera poliakrilat, biosensor menunjukkan ukuran pantulan yang tinggi dan stabil terhadap penentuan $60 \mathrm{mg}$ $\mathrm{mL}^{-1}$ ion $\mathrm{NO}_{2}^{-}$pada $668 \mathrm{~nm}$ sehingga hari ke-36 (Rajah 6) dan rangsangan biosensor mula menurun kepada $90 \%$ daripada isyarat asal biosensor selepas 36 hari penyimpanan biosensor. Hal ini menunjukkan molekul $\mathrm{Hb}$ terpegun kemungkinan mengalami penguraian tidak berbalik selepas disimpan dalam jangka masa melebihi sebulan. Dengan itu, biosensor optik tersebut mempunyai kestabilan operasi selama $\sim$ sebulan.

\section{KESIMPULAN}

Biosensor optik nitrit yang dibangunkan berasaskan $\mathrm{Hb}$ terpegun pada mikrosfera poliakrilat menunjukkan

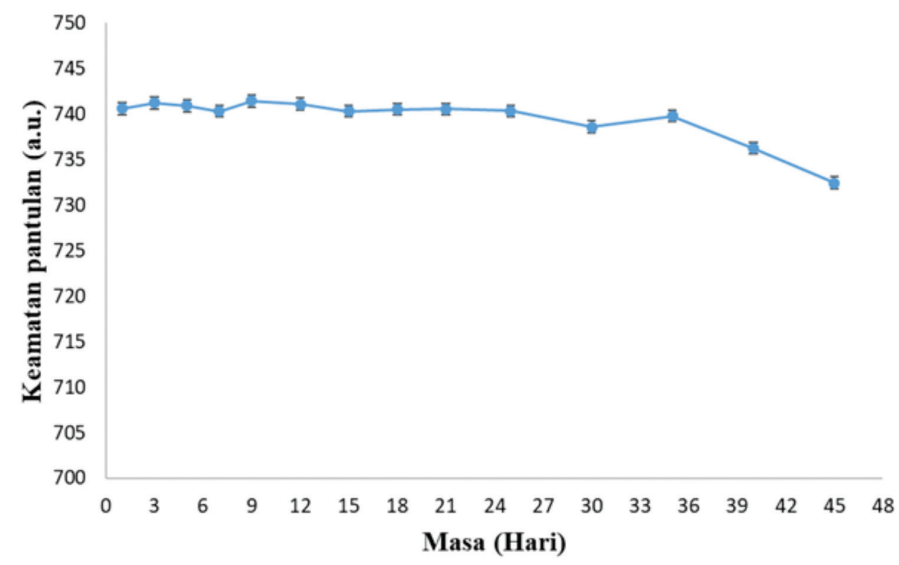

RAJAH 6. Profil jangka hayat biosensor ion $\mathrm{NO}_{2}^{-}$optik berasaskan $\mathrm{Hb}$ terpegun pada mikrosfera mikrosfera poliakrilat $(n=3)$ 
perubahan keamatan warna yang berkadar selari dengan kepekatan nitrit dalam larutan akueus. Oleh itu, biosensor optik terbangun mempunyai potensi untuk digunakan dalam penentuan semikuantitatif paras nitrit dalam sampel air persekitaran berdasarkan skala warna visual. Sebagai sebuah alat pengesan kepekatan ion $\mathrm{NO}_{2}^{-}$yang mudah diguna pakai oleh sesiapa sahaja akan mewujudkan kesedaran terhadap kepentingan menjaga kualiti air persekitaran. Bekalan air bersih yang mencukupi menjadi prasyarat kepada pembangunan ekonomi, pembasmian kemiskinan sekaligus meningkatkan kualiti hidup masyarakat

\section{PENGHARGAAN}

Penghargaan dan terima kasih yang tidak terhingga kepada Kementerian Pendidikan Tinggi yang telah membiayai Skim Geran Penyelidikan Fundamental (FRGS) dengan kod projek penyelidikan FRGS/2/2014/SG01/UKM/02/1.

\section{RUJUKAN}

Aschebrook-Kilfoy, B., Cross, A.J., Stolzenberg-Solomon, R.Z., Schatzkin, A., Hollenbeck, A. R., Sinha, R. \& Ward, M.H. 2011. Pancreatic cancer and exposure to dietary nitrate and nitrite in the NIH-AARP diet and health study. American Journal of Epidemiology 174(3): 305-315.

Bryan, N.S., Alexander, D.D., Coughlin, J.R., Milkowski, A.L. \& Boffetta, P. 2012. Ingested nitrate and nitrite and stomach cancer risk: An updated review. Food and Chemical Toxicology 50(10): 3646-3665.

Butler, A. 2014. Nitrites and nitrates in the human diet: Carcinogens or beneficial hypotensive agents? Journal of Ethnopharmacology 167: 105-107.

Cerqueira, B.A., Boas, W.V., Santana, S.S., Reis, J.O. \& Goncalves, M.S. 2013. Nitrite levels are associated to fetal hemoglobin concentration in patients with sickle cell anemia: Implications in inflammatory process. Blood 122(21): 46664666.

Koedrith, P., Thasiphu, T., Weon, J.I., Boonprasert, R., Tuitemwong, K. \& Tuitemwong, P. 2015. Recent trends in rapid environmental monitoring of pathogens and toxicants: Potential of nanoparticle-based biosensor and applications. The Scientific World Journal 2015: 1-12.

Moorcroft, M.J., Davis, J. \& Compton, R.G. 2001. Detection and determination of nitrate and nitrite: A review. Talanta 54(5): 785-803.
Quek, M.C., Chin, N.L., Yusof, Y.A., Tan, S.W. \& Law, C.L. 2015. Preliminary nitrite, nitrate and colour analysis of Malaysian edible bird's nest. Information Processing in Agriculture 2(1): 1-5.

Raja Dato' Zaharaton, R.Z.A. 2004. Water resources management in Malaysia: The way forward. Asia Water Conference 2004: $1-8$.

Robert, C.W. 1972. Handbook of Chemistry and Physics. Edisi Ke-53. Cranwood Parkway: The Chemical Rubber Co.

Samaneh,K., Rafiee, Z., Amin, M.M., Poursafa, P., Mansourian, M. \& Modaberi, A. 2013. Association of nitrate, nitrite, and total organic carbon (toc) in drinking water and gastrointestinal disease. Journal of Environmental and Public Health 2013: 1-4.

Tereshchenko, A., Bechelany, M., Viter, R., Khranovskyy, V., Smyntyna, V., Starodub, N. \& Yakimova, R. 2016. Optical biosensors based on $\mathrm{ZnO}$ nanostructures: Advantages and perspectives. Sensors and Actuators B: Chemical 229: 664-677.

Ward, M.H., deKok, T.M. \& Levallois, P. 2005. Workgroup report: Drinking-water nitrate and health - recent findings and research needs. Environmental Health Perspective 113(11): 1607-1614.

Wen, G., Wen, X., Shuang, S. \& Choi, M.M.F. 2014. Wholecell biosensor for determination of methanol. Sensors and Actuators B: Chemical 201(0): 586-591.

Syamimi Haslan, Ling Ling Tan*, Lee Yook Heng \& Goh Choo Ta Pusat Kajian Bencana Asia Tenggara (SEADPRI-UKM)

Institut Alam Sekitar dan Pembangunan (LESTARI)

Universiti Kebangsaan Malaysia

43600 UKM Bangi, Selangor Darul Ehsan

Malaysia

Lee Yook Heng

Pusat Pengajian Sains Kimia dan Teknologi Makanan

Fakulti Sains dan Teknologi

Universiti Kebangsaan Malaysia

43600 UKM Bangi, Selangor Darul Ehsan

Malaysia

*Pengarang untuk surat-menyurat; email: lingling@ukm.edu.my

Diserahkan: 13 April 2018

Diterima: 18 Mei 2018 